\title{
Lojistiğin Tarihsel Gelişimi: Askeri Gereksinimden İşletme Lojistiğine ve Tedarik Zinciri Yönetimine Evrilme Süreci
}

\section{Historical Development of Logistics: The Process of Evolution from Military Requirement to Business Logistics and Supply Chain Management}

\author{
R. Dilek KOÇAK, Türk Hava Kurumu Üniversitesi, Türkiye, r.dilekkocak@gmail.com \\ ORCID: 0000-0002-3077-0706
}

\begin{abstract}
Öz: Küreselleşen dünyada mal, hizmet ve bilginin yer değiştirmesi lojistik kavramı ile açıklanabilir. Kavram, insanliğın var oluşundan bu yana süregelmekle beraber, son yüzyllda bilimsel olarak irdelenebilmiştir. Lojistik temel olarak askeri gereksinimlerin bir sonucu olarak ortaya çıkmıştır. Ekonomi ve ticaretin gelişmesi, teknolojik buluşlar ve işletme düzeyinde etkinliklerin gelişimine bağll olarak, askeri nitelikli lojistik, işletme lojistiğine dönüşmüş ve 1950'li yıllardan sonra hızlı bir gelişme göstermiştir. 1980'li ve 1990'll yıllarda” Lojistik Yönetimi (LY)” ve “Tedarik Zinciri Yönetimi (TZY) " şeklinde farklılaşan lojistik kavramı, satın alma, üretim, depolama, envanter yönetimi, taşıma ve müşteri ilişkileri içeren çok boyutlu bir konsepte dönüşmüştür. Buradan yola çıkılarak lojistiğin tarihsel gelişimi irdelenecek, lojistiğin ortaya çıkış süreci ve sözcük anlamına değinilecektir. Ardından lojistiğin bir disiplin olarak ortaya çıkmasına yol açan askeri lojistiğin gelişimi incelenecektir. Bu kapsamda, lojistik stratejisinin gelişimine katkı sağlayan tarihsel olgular ve teknolojik gelişmeler ayrı bir başlık altında analiz edilecektir. Daha sonra, askeri lojistikten işletme lojistiğine geçiş süreci ve buna bağlı işletme lojistiğinin lojistik yönetimi ve tedarik zinciri yönetimi şeklinde farklılaşması ve Lojistik 4.0 anlayışı ele alınacaktır. Son olarak lojistik strateji kavramı ve olgusu tarihsel süreç ve lojistik ve tedarik zinciri bağlamında irdelenecektir.
\end{abstract}

Anahtar Sözcükler: Lojistik Stratejisi, Lojistik Tarihi, Askeri Lojistik, İş Lojistiği, Tedarik Zinciri Yönetimi, Lojistik 4.0

JEL Siniflandirması: M10, M19, R49

Abstract: In a globalizing world, the movement of goods, services and information can only be explained by the concept of logistics. Although the concept has continued since the existence of humanity, it has been scientifically examined in the last century. The concept of logistics has emerged mainly because of military requirements. Depending on the development of economic and trade, technological inventions and the progresses at the business level, military logistics has shifted to a business logistics and started to develop rapidly after 1950s. In the 1980s and 1990s, the concept of logistics, which differentiated into" Logistics Management (LM)" and "Supply Chain Management (SCM)", became a multi-dimensional concept that included purchasing, production, storage, inventory management, transportation and customer relations. From this point, the historical development of logistics will be examined. In this perspective, firstly, the process for emergence of logistics and the meaning of the word will be discussed. Then, the military logistics development leading to the emergence of logistics as a discipline will be examined. In this context, historical facts and technological developments that contribute to the development of logistics strategy will be analyzed under a separate heading. Then, the transition process from military logistics to business logistics will be analyzed and the differentiation of business logistics in the form of logistics management and supply chain management and Logistics 4.0 understanding will be discussed. Finally, the concept and phenomenon of logistics strategy will be scrutinized in the context of historical process and logistics and supply chain.

Keywords: Strategy of Logistics, History of Logistics, Military Logistics, Business Logistics, Supply Chain Management, Logistics 4.0

JEL Classification: M10, M19, R49

\section{Giriş}

Lojistik, insanlığın en temel gereksinimlerinden biri olan varlığını sürdürme ve güvenliğini sağlama olgusuyla beraber gelişmiştir. İnsan toplulukları, güvenliklerini sağlamak için kurdukları korunma gücünü, beslenme ve diğer gereksinimlerini karşılamak için lojistik sistemleri geliştirmişlerdir.

Lojistik, başlangıçta orduların ikmalini destekleme faaliyetleri için kullanılan bir kavram olarak ortaya çıkmıştır. Tarihsel arka planda, ekonomi ve ticaretin gelişmesi, teknolojik buluşlar ve işletme düzeyinde etkinliklerin gelişimine bağlı olarak, askeri nitelikli lojistik, işletme lojistiğine dönüşmüş ve bu durum 1950'li yıllardan sonra hızla gelişme göstermiştir. Teknolojik ve ekonomik gelişmeye paralel olarak, işletme lojistiğinin odak noktası başlangıçta, malların fiziki dağıtımı olduğundan, kavram olarak fiziksel dağıtım şeklinde nitelendirilmiştir. Ancak işletme lojistiği, daha sonra, Lojistik Yönetimi ve Tedarik Zinciri Yönetimi şeklinde fonksiyonel ayırıma tabi tutulmuştur. Kuramsal çalışmalarda, her iki kavramın niteliği ve ilişkileri bağlamında farklı görüşler ileri sürülmüştür. Tarihsel süreçteki ekonomik gelişmeler, devletlerarasındaki savaşlar için ihtiyaç duyulan asker, malzeme ve silahın taşınma gereksinimleri, 18. yüzyılın sonlarından itibaren ulus devletlerin varlıklarını ve güvenliklerini korumak için kurdukları kitle ordusu (mass army) olgusunun yol açtığı taşıma ve depolama gereksinimleri, küreselleşme, sanayileşme ve devletlerarası ticaretin gelişmesi gibi faktörler lojistiğin gelişimine katkı sağlamıştır.

Çalışmada lojistiğin tarihsel gelişimi incelenecektir. Bu açıdan çalışma geleneksel literatür taramasıdır. Öncelikle lojistiğin ortaya çıkış süreci ve sözcük anlamına değinilecek, lojistiğin bir disiplin olarak ortaya çıkmasına yol açan askeri lojistik gelişimi ele alınacak ardından, askeri lojistikten işletme lojistiğine geçiş süreci analiz edilecek ve buna bağlı işletme lojistiğinin lojistik yönetimi ve tedarik zinciri yönetimi biçiminde farklılaşması ve Lojistik 4.0 anlayışı ele

\section{Makale Gecmiși / Article History}

Başvuru Tarihi / Date of Application Kabul Tarihi / Acceptance Date
: 14 Kasim / November 2019

: 19 Aralı / December 2019 
alınacaktır. Son olarak lojistik stratejisi kavramı, tarihsel süreç, lojistik ve tedarik zinciri bağlamında irdelenecektir ve elde edilen bilgiler ışığında sonuç ortaya koyulacaktır.

\section{Lojistik Kelimesinin Kökeni}

Dilimize "lojistik" olarak yerleşen sözcüğünün kökeni ve anlamına ilişkin farklı bilgiler söz konusudur. Ancak, farklı yorum ve bilgileri birbirlerini tamamlayan bilgiler manzumesi olarak görmek gerekir. Türk Dil Kurumu (TDK, 2019) lojistik kavramını "kişilerin ihtiyaçlarını karşılamak üzere her türlü ürünün, hizmetin ve bilgi akışının çıkış noktasından varış noktasına kadar taşınmasının etkili ve verimli bir biçimde planlanması ve uygulanması" olarak ifade etmiştir.

Lojistik kelimesinin, orta çağ dönemi Latince sözcüğü olan logisticus ve Yunan orijinli logistikos kelimesinden üretildiği ifade edilmektedir. Bu kelimeler; mantık anlamındaki "logic” ile istatistik anlamındaki "statics"dir. Bu noktadan bakıldığında sözlük anlamının "mantıklı hesap" olarak ifade edilmesi yanlış olmaz. Yine Yunanca Logistikos kelimesi ele alındığında, "hesap, kitap yapma bilimi”, "hesapta becerikli” anlamına geldiği ifade edilir. Birleşik anlam olarak, "mantıklı hesaplama" şeklinde de söylenebilir (Wassenhove 2006, 475). Kelimenin logic kökeninin "hesap" olduğu Logistics kelimesinin ikinci kısmınınsa, Yunanca ikon kelimesinden geldiği ve "resim" kelimesini ifade ettiği de belirtilmiştir. Yunancadan yapılan çevirilerde lojistik, "resimli matematik sanatı" olarak ifade edilmiştir. Bu nedenle, "logos + icon" bileşik kelimesi fonolojik ${ }^{1}$ ve morfolojik ${ }^{2}$ bir uyarlamadır (Tepic, Tanackov ve Stojić 2011, 379). Lojistik kelimesinin etimolojisinin ${ }^{3}$ iki kelimeye dayandığı söylenebilir, "hesap ve resim" ya da "görüntü yoluyla sayısal beceriler" (Tepic vd. 2011, 383).

Lojistiğin doğuşunun Yunan ve Roma imparatorluklarına kadar uzanabileceğini belirtildiğinden söz konusu kelimenin anlamı doğrulanır niteliktedir. Lojistik kelimesi askeri bir terim olarak "ulaştırma, tedarik ve askeri birlikleri doğru yerlere uygun bir şekilde yerleştirme sanatı" anlamında kullanılmaktaydı (Wolff ve Y1ldız 2018, 188). Bu imparatorluklarda, kaynakların tedariki ve dağıtımı ile ilgili hizmetlere verilen subaylar, "Logistikas" olarak adlandırılırdı. Bu sistem, askerlerin ana üslerinden ileri üslere hızlı bir şekilde ilerlemelerini sağlamak için yapılmıştır. Sistem, aynı zamanda düşmanın tedarik üslerine zarar vermek ve kendi tedarik üslerini korumak anlamına da geliyordu. Tarihteki bu uygulamalar, günümüz lojistik yönetim sistemi ortaya çıkışına zemin hazırlamıştır (bestlogisticsguide.com). Başka bir kaynakta ise, lojistik kelimesinin, Napolyon Bonaparte zamanında askerlere kalacak yer bulmaktan sorumlu şefin görevi olan "logistician"' teriminden türetildiği belirtilmiştir (Azmia vd. 2017, 73). Bu görüş de lojistik sözcüğünün Yunan ve Latin dillerinden evrilmiş olduğunu ortaya koymaktadır.

Dünyada ilk defa "lojistik" sözcüğünün Henri de Jomini tarafından 1838 tarihinde yayımlanan The Art of War (Savaş Sanatı) adlı eserde geçtiği ifade edilmiştir. Diğer taraftan "lojistik” sözcüğünün İngilizce makalelerde 1898'den itibaren yer aldığı belirtilmektedir (Robinson, 2015). Ancak bazı kaynaklarda, dünyada ilk defa İngilizce "lojistik" sözcüğünün içeren kitabın, Dr. William Muller tarafından 1810'da yazılan The Elements of the Art of War ${ }^{4}$ (Savaş Sanatının Öğeleri) adlı kitapta geçtiği belirtilmiştir. Bununla birlikte, Supply Chain (Tedarik zinciri) ibaresinin de ilk defa, The Independent gazetesinin 1905 yılı baskısında geçtiği, ayrıca yine Glasgow Herald gazetesinin 12 Ekim 1912 tarihli baskısında, Balkan Savaşı'nın askeri ikmal yönü ile ilgili bir haberde "Supply Chain (Tedarik Zinciri)" ibaresi geçtiği bilinmektedir (www.supplychainopz.com). Bu bakımdan ortaya çıkan yeni bilgiler bağlamında daha önce doğru bilinen bazı hususların değişmiş olduğunu görmekteyiz.

Lojistik kavramsal olarak yaşamımıza son yüz y1l içinde girmesine karşın, tarih boyunca insanoğluyla beraber varlığını sürdürmüştür. Tarihsel süreçte çok dar anlamda "ulaştırma" olarak kabul edilen lojistik, bugünkü içeriği kadar bütünleşik anlamlar içermemekteydi. Zaman içinde lojistik, bir faaliyet olarak iş dünyasında, ürün veya hizmet akışının ilk noktasından tüketim noktasına doğru yönetilmesi şeklinde evrilmiştir.

\section{Lojistiğin Dayană̆ı: Askeri Gereksinim}

Askeri kökenli bir kavram olan lojistik, birliklerin ihtiyacı olan ulaşım, beslenme, destek, iletişim, sıhhiye gibi muharebe hizmet destek faaliyetlerini ifade eder. Askerî harekâtın gerçekleştirilmesi için gerekli ana sistem, teçhizat, depolama, nakliyat ve dağıtım, tahliye, elden çıkarma gibi faaliyetlerin bir sistem sorumluluğu içinde istenen yerde, istenen zamanda etkin ve verimli olarak yerine getirilmesi şeklinde ifade edilebilir.

Tarihte Büyük İskender, Cengiz Han ve Napolyon ordularıyla ilerlerken, askerlerinin beslenme ihtiyaçları için lojistik stratejileri ve sistemleri geliştirmişlerdir. Dünya tarihinde en uzun ve aralıksız askeri sefer Büyük İskender komutanlığında yürütülmüştür. Bahsi geçen askeri sefer M.Ö. 334-323 yılları arasında on bir yıl sürmüştür. Zor doğa ve iklim koşulları ile bilinmedik yerlere doğru açılan Büyük İskender ve ordusu Makedonya'nın doğusundan Hindistan'a kadar ulaşmıştır (www.supplychainmovement.com). Savaşların büyüklüğü ile orduların yürüyüşleri ve intikalleri sırasında, önemli miktarda güvenilir tedarik kaynağı ihtiyacı doğmuştur (Grant 2012, 4). Örneğin Roma lejyonu, savaş

\footnotetext{
${ }^{1}$ Fonoloji: Ses Bilimi

${ }^{2}$ Morfoloji: Biçim Bilimi

${ }^{3}$ Etimoloji: Köken Bilimi

4 "1811 yılında Muller kitabın adı ile ilgili fikrini "The Elements of the Science of War" (Savaş Biliminin Unsurları) şeklinde değiştirmiştir "(www.supplychainopz.com).
} 
meydanlarına varmak için intikallerini esnek bir sistem kullanarak gerçekleştirmiştir. Bunun için Lejyonun hızlı bir şekilde ilerleyebildiği mükemmel yollar yapılmış, mobil tamir atölyeleri inşa edilmiş, bakım ve tamir ekipleri oluşturulmuştur. Ordunun gereksinimleri, yol üzerindeki bölgesel ve yerel unsurlardan karşılanmıştır. Gerektiğinde lojistik unsurlarla birlikte kesintisiz 30 güne kadar intikaller yapılmıştır. Örneğin, Kartacalılara karşı İlk Punik Savaşı'nda (264-241 M.Ö.), bir Roma ordusu dört hafta boyunca günde ortalama 26 kilometre yol yürümüştür (www.britannica.com).

Savaş gereksinimlerine yönelik lojistik sistem, kaçınılmaz olarak çeşitli askeri seferlere hizmet eden bağımsız bir yardımcı sistem oluşturmuştur. Bu bakımdan bir askeri lojistik stratejisi ortaya koyulmuştur. Bu bağlamda, intikal mesafesi, intikal vasıtası (hayvan, yaya, demiryolu, karayolu, hava yolu veya deniz yolu sistemi veya bunların karışımı), intikal ettirilecek askeri güç, savaş bölgesindeki risklere bağlı olarak askeri lojistik stratejisi belirlenmiştir. Daha sonra lojistik stratejiye de temel teşkil edecek askeri lojistik strateji; esas olarak uygun yöntem, vasıta veya kaynak kullanarak savaşacak olan ordunun desteklenmesini üzerine yoğunlaşmıştır. Bu bakımdan, Büyük İskender, askeri lojistik stratejisini uygun bir şekilde kullanabilen ilk büyük lider olarak tarihte yerini almış ve orduları ile Avrupa, Afrika ve Uzak Doğu alanında büyük bir imparatorluk kurmuştur. İskender M.Ö. 300 yıllarında deniz aşırı askeri intikalleri, gemilerle gerçekleştirmiştir. Gemi inşası, lojistik ulaştırma stratejisi tarihinde önemli bir yer teşkil etmektedir (Cuturela ve Manole 2013, 194). Diğer yandan, şimdiye kadar bilinen en uygun veya verimli lojistik stratejilerinden biri, 13. yüzyılın Moğol süvari orduları tarafından uygulanan sistemdir. Moğol süvarilerinin gerisinde, ordu yükü arabaları, güçlü taşıma hayvanları ve sığır sürüleri eşlik etmiştir. Otlatma ve gıda ürünlerine erişim için yollar ve kamp alanları seçilmiştir. Yollar boyunca yiyecek ve yem önceden depolanmıştır. Bu yöntemler sayesinde bir Moğol ordusu, düşmanına yaklaşma anında üç gün içinde 290 kilometre yol gidebilmiştir (www.britannica.com). Böylelikle, Moğol orduları, hızlı, etkin, basit lojistik stratejisi ile çok hızlı intikal edebilen ordularını desteklemiştir.

Orta Çağ döneminde ordular sayısal olarak küçük olduklarından bunların ikmalinde büyük sorun yaşanmamıştır. Ancak bu dönemde lojistik stratejide büyük değişim yaşanmıştır. Bu değişim orduların ikmalinde depolama sisteminin kullanılmaya başlanması ile gerçekleşmiştir. Bu kapsamda, “orduların ikmali için depoların teşkil edilmesi ilk defa 1311 yılında Fransa Kralı Phillippe Le Bel tarafından gerçekleştirilmiştir” (Çetin ve Kök 2015, 5). Depo sisteminin kullanılması suretiyle lojistik stratejideki bu değişim daha sonraları işletmelerin lojistik stratejilerini etkilemiştir. İnsanlık savaşları tarihi boyunca lojistik güçler ve kabiliyetler ya da bunların eksikliği ile kazanılmış ve kaybedilmiştir. İngilizlerin Amerikan Kurtuluş Savaşı'ndaki yenilgisinin büyük ölçüde lojistik başarısızlığına bağlı olabileceği iddia edilmiştir. Amerika'daki İngiliz ordusu, tedarik için neredeyse tamamen İngiltere'ye bağlıydı. Savaşın zirvesinde denizaşırı ülkelerden 12.000 asker vardı ve çoğu zaman sadece donatılmaları için değil, beslenmeleri de İngiltere'den de gerekiyordu. Savaşın ilk altı yılında, bu hayati kaynakların yetersiz yönetimi, harekâtın gidişatını ve birliklerin moralini etkilemiştir. Orduya lojistik destek sağlayabilecek bir örgütlenme ancak 1781 yılında yapılabildi ancak, savaşı kazanmak için geç kalınmıştı (Christopher 2011, 1).

Fransız Devrimi ve Avrupa'nın Napolyon hâkimiyeti (1789-1815) dönemi, orduların hem hareketliliğini hem de sayısının arttığı dönem olmuştur. Napolyon'un büyük bir ulusal orduyu oluştururken karşılaştığı lojistik eksiklikler, daha önce görülmemiş bir ölçekte sorunlar ortaya koymuştur. Bu sorunları gidermek için, Fransız Ordusu'nun tedarikten sorumlu organizasyonun başkanı Claude-Louis Petiet dört savaş komisyonu geliştirmiştir; ekmek pişirme, nakliye, yiyecek toplama ve et işleme. Her komisyon üyesi bir tedarik konusu ile ilgilenmiştir (Hammod, 2012). Eski rejimden miras alınan lojistik sistem, hızlı intikal edebilen ordu sistemine uyarlanmıştır. Ordunun gerisinde intikal ettirilen yüklerin bir kısmı askerin sırtına kaydırılarak hareketlilik artırılmış ve topları ordunun arkasında taşıyan bir sistem geliştirilmiştir. Napolyon'un 1812'de 600.000 kişiden oluşan Grande Armée ile Rusya'ya 600 mil kadar ilerlemesi, büyük ölçekte lojistik altyapısı içeriyordu. Rus köylülerinin geniş çaplı sabotajlarına rağmen, sistem orduyu zaferle Moskova'ya getirmiştir (www.britannica.com).

Osmanlı imparatorluğu lojistik faaliyetlerini stratejik olarak en etkin ve başarılı yürüten imparatorlukların başında tarih sayfalarında yer almaktadır. Osmanlı'da sefer kararı alındığı vakit ilk önce bölgedeki lojistik ve stratejik imkânlar devreye sokulmuştur (Kurtaran 2012, 2271). Sefere çıkılmadan belirli bir süre önce, sefer yolu üzerinde, ilgili beylerbeyi vasıtasıyla belirli ikmal noktaları tesis edilmekteydi. Ordu sefere çıktığında, bu ikmal noktaları civarında ordugâha geçiliyordu. Bu da kısmen Roma İmparatorluğu'nun ikmal sistemine benzemekteydi. Osmanlı İmparatorluğu'nda sefer öncesi ve sefer sırasında yürütülen günümüzde "lojistik" olarak ifade edilen bu tür faaliyetlere kısaca iaşe, ikmal deniyordu (İşbilir 1996). Osmanlı padişahları yapılan savaşlarda, ordularının askerî faaliyetlerini başarılı bir biçimde yürütebilmesi adına, silahların, cephane, erzak, yem ve malî kaynakların ihtiyaç duyulan bölgelere hızla ulaştırılmasına stratejik açıdan oldukça önem vermiştir (Kurtaran 2012, 2270).

19. yüzyılın ortaları ile 20. yüzyılın ortaları arasında lojistik şartları ve yöntemleri, savaşın araçları ve biçimlerindeki devrimsel değişiklikleri beraberinde getirmiştir. Bunlar;

(1) çok büyük kitle ordularının seferber edilmesi; (2) silah teknolojisinde ve ateş gücünde olağanüstü artış içeren bir devrim; (3) kitle ordularını beslemek, silahlandırmak ve taşımak için araçlar sağlayan ekonomik bir devrim ve (4) askeri kurumlarını daha önce hiç olmadığı kadar etkin bir şekilde kullanmalarını sağlayan yönetim ve örgütlenme tekniklerinde bir devrim olarak sıralanabilir (www.britannica.com ). 
$\mathrm{Bu}$ dört önemli faktör, büyüyen milli orduların savaşta ikmalini sağlayacak bilimsel lojistik kavramının doğuşuna sebep olmuş ve ordu liderlerini lojistik planlamaya yöneltmiştir. Nitekim lojistiğin önemini gören Mustafa Kemal Paşa'nın;

07 Ağustos 1921 tarihinde yayınladığı “Tekâlif-i Milliye Emirleri’ nin 5. ve 10. maddelerinin, ordunun ihtiyaç duyacağı malzemelerin, ulaştırma araçlarının, hayvanların ve hizmetlerin tedarik edilmesi” ile ilgili olduğu bilinmektedir (Kayıran 1989, 650).

\subsection{Lojistik Stratejisinin Gelişimi: Tarihsel Arka Plan}

Lojistik, insan toplumunun gelişmesinde mutlak gerekli olan bir bileşen olarak varlığını kanıtlamış, bu tarihsel gelişimde ise bazı önemli teknolojik gelişmeler rol oynamıştır. Nasıl ki ateşin buluşu insanoğlunun varlığının korumasında önemli bir oynamışsa, tekerleğin icadı da uygarlı̆̆ın gelişmesinde önemli bir faktördür. Aynı zamanda lojistik stratejisinin temelini oluşturan ulaşım kavramını insanoğlunun hizmetine sunmuştur. İnsanoğlu tekerlek sayesinde uzak mesafelere büyük yüklerle taşınma imkânı bulmuştur. Bu icada bağlı olarak gelişen taşımacılık binlerce yıl içinde küreselleşmenin de itici gücüyle etkin bir faktör haline gelmiştir. Dolayısıyla İnsanlığın son 5000 yıldaki gelişiminde, lojistiğin önemli bir rol oynadığını söylemek mümkündür.

Lojistik istisnai bir olgudur. Tepic, Tanackov ve Stojić $(2011,379)$ lojistiğin temellerinin Tunç Çağı'na dayandığını ifade etmişlerdir. Bahsi geçen temellerin sayısal sistemlerden oluşan metrik bir sistem olduğudur. Mezopotamya ve Mısır kökenli sayısal sistemler Fenikeliler tarafından ticari amaçlarla kullanılmıştır. O zamanlar sayılar sembol olarak değil, resim olarak gösterilmekteydi. Bilinen en eski gemi batığı olan Antalya Kaş açıklarındaki Uluburun batığında (M.Ö. 1300) yapılan detaylı analizler, Akdeniz'de Tunç Çă̆'ına dayanan yoğun üretim ve ticari faaliyetler olduğunu kanıtlamıştır. Bu faaliyetlerin yalnızca yoğun lojistik faaliyetlerin desteği ile gerçekleştirilebileceğini söylemek mümkündür (Tepic vd. 2011, 380).

Tarihsel açıdan lojistiği anlamlandıracak faaliyetlerden birisi eski Mısır'da piramitlerin yapılması sürecidir. Antik dönemde Mısır'daki piramitlerin inşası lojistik anlayışının ve bilginin yansıtılması açısından önemlidir. Örneğin, son arkeolojik bulgular, 20 yıllık inşaat projesinde yer alan hayranlık uyandıran lojistiği ortaya koymaktadır. Eski Mısır'da M.Ö. 2700'lerde malzeme işleme teknolojileri ve piramitleri inşa etmek için kullanılan inşa ve taşınma sistemlerinde çok ileri bir teknoloji varlığını düşündürmektedir. 146 metre yüksekliğinde ve ağırlığg 6 milyon ton olarak hesaplanan Büyük Giza Piramidi’ni (Keops Piramidi) inşa etmek için, eski Mısırlıların, muazzam taş blokları hareket ettirebilecek teknolojiye sahip oldukları düşüncesi halen şaşkınlık uyandırmaktadır. Eski Mısır'da nakliye konteynerinin icadının yanı sıra, yapı ve malzemelerinin taşınması için yaratılan tekniklerin de günümüzde halen araştırma konuları olduğunu görmekteyiz. Bu anlamda, uygarlık aşamalarının birinden diğerine geçişin, başka bir deyişle bir tarihsel süreçten diğerine geçişin, parlak lojistik çözümler vasitası ile sağlandığı söylenebilir (Cuturela ve Manole 2013, 193). Antik Misır'da lojistiğin etkilediği yaşam alanını inceleyen arkeologlar Nil Nehrinin ana ulaştırma hattı olarak yer aldığını ifade etmektedirler. Arkeolojik kanıtlar, lojistiğin Antik Misır Devletinin diğer ülkelerden gerekli hammaddeleri ithal etmesinde, etkileyici bir ordu kurmasında ve tüm Mısır halkının yaşam gereklerini sağlamasında etkin olduğunu göstermektedir (Pelletier 2013, 197).

Lojistik ve küreselleşme tarihi açısından diğer önemli bir gelişme ise, Yunan şehir devletleri zamanında, gemilerin, insan ve malzeme taşımasında kullanılması için dönüştürülmesidir. Devrimsel bir anlam içeren bu teknolojik dönüşüm, Fenike gemilerinin yapısına dayanıyordu; savaş gereksinimi nedeniyle aynı anda çok fazla savaşçı ve savaş malzemesini taşımayı hedeflemekteydi. Gemi yapım teknolojilerindeki bu ve benzeri devrim niteliğindeki icatlar, denizler üzerinde hızlı bir yolculuk ile malzeme ve insan taşımacılığının temelini oluşturmuştur (Cuturela ve Manole 2013, 194). MÖ 500400' lerde ticarette de kullanılan bu gemilerin çoğu yaklaşık 150 ton ağırlığındaydı. Daha sonra, Helenistik dönemde insanlar yaklaşık 400 tonluk daha büyük gemiler inşa ettiler. Taşımacılıkta da kullanılan bu gemiler; genellikle şarap, buğday, zeytinyağı, parfüm, cam bardak ve vazolar, mücevher ve kıyafetler, taştan ve metalden yapılmış aletler taşıdılar (https://quatr.us).

Endülüs Emevileri Devleti döneminde İspanya-Cordoba'da inşa edilen Mezquita (Kurtuba) camisi büyük bir lojistik ulaştırma sistemi sayesinde gerçekleşmiştir. Caminin tarihi M.S. 700'lü yıllara dayanmaktadır (Fiorin, 2019). İslam İmparatorluğundan İspanya'ya taşınan ve 856 sütun oluşan bu caminin malzemeleri, şüphesiz ki büyük bir lojistik ikmal sistemin varlığını gerektirmekteydi (Cuturela ve Manole 2013, 194). 1200'lü yıllara gelindiğinde her dönem ticaretin en önemli unsuru olan ve tarihi M.Ö. 3200'e dayanan deniz taşımacılığının da etkin, emniyetli ve lojistik anlamda küreselleşmeyi destekleyecek biçimde geliştiği görülmektedir. Bu gelişmenin en önemli adımının ise Hanseatic Leaque (Hanseatic Birliği) tarafından Almanya’nın Hamburg kentinin merkez alınarak sağlandığı bilinmektedir. Bu ticari adım, deniz lojistiğinin gelişmesinin önemli bir safhasını oluşturmuştur. Kuzey Denizi, Kuzey Afrika, Akdeniz ve Karadeniz limanlarında deniz ticareti böylelikle gelişmiştir (Cuturela ve Manole 2013, 194). Günümüzde Avrupa ticaretinin \% 75'nin ağırlıklı denizyolu ile gerçekleştirildiği (Erdönmez ve İncaz 2016, 115) düşünüldüğünde 1200’lü yılların deniz lojistiği anlamında önemli dönemler olduğunu söyleyebiliriz.

Lojistik sistem ve küreselleşme anlamında diğer bir katkı sağlayıcı faktör, 16. yüzyılda Avrupa'daki posta sisteminin tüm kıtayı kapsayacak şekilde genişlemesidir. Aynı yüzyıl İngiliz ve İspanyol İmparatorluklarının genişlemesi deniz 
nakliyat sisteminin gelişmesine de yol açmıştır. "Franz von Taxis", transit şartlarının tanımlandığı ilk posta hizmetini organize eden kişi olarak, tarih sayfalarında yerini almıştır (Cuturela ve Manole 2013, 195).

Yukarıda ifade edildiği üzere, kavram olarak askeri uygulamalarla başlayan lojistik kavramı, zamanla, askeri alandan ana ticari arenaya taşınmıştır (Sweeney, Grant ve Mangan 2017). Bu kapsamda, 1800’lerden itibaren ortaya çıkan Endüstri Devrimi ulaşım ve taşıma sistemlerine köklü değişiklikler getirmiştir; Demiryolu, karayolu ve denizyollarının sanayi devriminin gereksinimi haline gelmesi, hammaddenin ana üretim merkezlerine taşınması ve yine üretilen malların pazar noktalarına iletilmesindeki rolleri ile lojistik sisteminin devrimsel dönüşümüne öncülük etmiştir (Cuturela ve Manole 2013, 195).

İkinci Dünya Savaşı'ndan sonra lojistik faaliyetler, büyük oranla savaş odağından çıkarak iş dünyası odağına kaymıştır. Ürünlerin fiziksel dağıtımı, ticari işletmelerin esas olarak yoğunlaştığı lojistik faaliyet alanı haline gelmiştir. Taleplerin alınması, hammaddenin girişi, ürünün hazırlanması, dağıtılması, depolanması, üretim planlaması ve müşteri hizmetleri, lojistik sürecinin önemli faaliyetleri olarak ortaya çıkmıştır (McGinnis 1992, 25).

Tablo 1. Lojistiğin Evriminde Önemli Tarihsel Olgular

\begin{tabular}{|c|c|}
\hline M.Ö.2700’ler & $\begin{array}{l}\text { Misır Piramitleri Yapımı-Taşıma teknolojisi- Tonlarca ağırlıktaki taş bloklar şantiyeye taşındı ve } \\
\text { birleştirildi. }\end{array}$ \\
\hline M.Ö. 300’ler & Devrimci Yunan kürek gemileri- Kitalararası ticaretin temeli atıldı. \\
\hline M.S. 700'ler & $\begin{array}{l}\text { Cordoba' daki ünlü Mezquita Camii inşaatı- Sütunlarının tedarik lojistiği ile İslâm imparatorluğunun } \\
\text { her yerinden İspanya'ya getirildi. }\end{array}$ \\
\hline 1200’ler & $\begin{array}{l}\text { Hamburg-Almanya Hansa Birliği olarak bilinen uluslararası ă̆- Denizde seyahat etmeyi daha } \\
\text { güvenli hale getirmek ve yurtdışındaki ticari çıkarlarının temsil edilmesi için Kuzey Denizi'nde bir } \\
\text { üs olarak kuruldu. }\end{array}$ \\
\hline 1500 'ler & $\begin{array}{l}\text { Avrupa'da ilerici posta servisi- İlk kez kesin posta gönderim hizmeti. Mektuplar Paris, Gent, İspanya } \\
\text { ve Viyana imparatorluk mahkemesi gibi yerlere ulaştırıld. }\end{array}$ \\
\hline 1800’ler & $\begin{array}{l}\text { Yeni karayolu taşımacılığının ve demiryolunun keşfi- Lojistik teknolojileri yeni tekno } \\
\text { geliştirildi ve nakliye araçlarıyla genişletildi. }\end{array}$ \\
\hline 1940 'lar & nda askeri lojistik- Askeri lojistik kavramları iş dünyasına aktarıldı. \\
\hline 1956 & $\begin{array}{l}\text { Deniz konteynerinin icadl- Dünya ticaretinin yapısal gelişimi ve uluslararası mal akışı son derece } \\
\text { hızlandı. }\end{array}$ \\
\hline $1970-1980$ & $\begin{array}{l}\text { KANBAN ve Tam Zamanında - Yeni Lojistik kavramları ile tedarik konusuna özel vurgu yapıldı. } \\
\text { Konseptler, Taiichi Ohno tarafından Japonya'nın Toyota Motor Şirketi'nde geliştirildi ve tanıtıldı. }\end{array}$ \\
\hline 1990 & $\begin{array}{l}\text { QR ve ECR Teknolojileri- Dağıtıma özel önem veren lojistik konseptler geliştirildi. Hızlı cevap (QR) } \\
\text { ve verimli tüketici cevap (ECR) teknolojileri 1990’lı yıllarda geliştirildi ve birçok perakende ve } \\
\text { toptan satış şirketi tarafından uygulandı. }\end{array}$ \\
\hline Günümüz & $\begin{array}{l}\text { Tedarik zinciri yönetimi- Satıcının tedarikçisinden son müşteriye kadar tüm lojistik zincirine bir } \\
\text { bakış. }\end{array}$ \\
\hline
\end{tabular}

Kaynak: Cuturela ve Monole 'nin (2013, 188-198) “A Short Historical Perspective on the Evolution of Logistics and its Implications for Globalization” adlı çalışmalarından yararlanılarak oluşturulmuştur.

\section{Bilimsel Disiplin Olarak Lojistik}

Literatür incelendiğinde, lojistik faaliyetlerin bilimsel olarak ele alınışının 1905 yılına dayandığı görülmektedir. Lojistik kavramı orduların malzeme ve personelin taşıma, tedarik, bakım ve yenilenmesi faaliyetlerini kapsayan işlemlerin bütününü tanımlamak üzere kullanılmıştır. Bu süreç, 20. yüzyılın başlarında, endüstri devrimiyle insanların kırsaldan kentlere büyük oranda göç edişi başladıktan sonra, tarımsal veya çiftlik üretiminden pazar ekonomisine geçiş ile malların fiziki dağıtım sürecine doğru yönelmiştir (Grant 2012, 5). Dolayısıyla; askeri lojistik kavramı bilimselliğe evrilirken, diğer yandan küresel ekonomik gelişmelerde lojistiğin ticari yaşamda kullanılmasının önünü açmıştır. Bu kapsamda, lojistiğin bir bilim dalı olarak gelişiminin; zaman ve yer faydası sağlanması açısından tarımsal ürünlerin dağıtımı 1900'lü yılların başlarına dayandığı söylenebilir (Erkan 2014, 47). 1950 yılından sonra, dünya ekonomisindeki yapısal değişimler ve eğilimler lojistik kavramının daha da gelişmesine imkân vermiştir.

1900'lü yılların ilk çeyreğine gelindiğinde Henry Ford'un öncülüğünü yaptığ1 Fordist üretim sisteminin ABD'de uygulanmaya başladığı ve Avrupa'da yayıldığı görülmektedir. Böylelikle hammaddenin, yarı işlenmiş ve işlenmiş ürünlerin tedarik, taşıma ve ürünün teslimat faaliyetleri de büyük ölçüde önem kazanmıştır (Erkan 2014, 46). Fordizm ile gelen kitle üretim rejimi; malların taşınmasının, depolanmasının, dağıtım merkezleri oluşturmasının ve müşteri ilişkisi fonksiyonlarının gerekliliğini ortaya koymuştur.

İkinci Dünya Savaşı sırasında (1939-1945), sayısal olarak çok büyük orduların ana kıtadan çok uzaklarda muharebeye girişmesi, lojistiği evrim dinamiğini hızlandırmış ve bilimsel yönden zenginleştirmiştir. Savaş yıllarında ABD ve müttefiklerinin ordu lojistiğinin sistemsel olarak etkin oluşu dikkat çekmiştir. Savaş sonunda elde edilen zaferin 
bir nedeninin, ABD’nin ordu lojistik sistemini etkin kullanmış olduğu şeklinde değerlendirilmiştir. İkinci Dünya savaşı boyunca $\mathrm{ABD}$ ve müttefik orduları o güne kadar örneği görülmemiş, sayısız problemlerle karşılaşmış ve kendi zamanları için dikkate değer bir dağıtım sisteminin geliştirilmesine öncülük etmişlerdir (bestlogisticsguide.com). Ayrıca, İkinci Dünya Savaşı sırasında ABD ve müttefiklerinin lojistik sistemlerinin Alman ordusunun lojistik sisteminden daha etkin olduğu da değerlendirilmiştir (Christopher 2011, 14). Alman silahlı kuvvetlerinin tedarik üsleri karşıt kuvvetler tarafından ciddi hasarlara maruz bırakılırken, Almanya karşı tarafta aynı hasara yol açamamıştır. ABD ordusunun, hizmet ve malzemeleri doğru zamanda ve doğru yerde sağlayarak, lojistik sistemini etkin şekilde kullanmış olduğu ifade edilmektedir. $\mathrm{Bu}$ sistemler, daha gelişmiş bir biçimde de zamanımız orduları tarafından halen kullanılmaktadır (bestlogisticsguide.com.).

Sonuç olarak, 1950’lerden önce lojistik, askeri disiplin konularından biri olarak ele alınmış (Ballou 2007, 333) askeri tesislerin, malzemelerin ve personelin tedarik, bakım ve nakliyesi ile ilgili bir kavram olarak kalmıştır (Heskett vd. 1973). İkinci dünya savaşı boyunca lojistik faaliyetlerde yaşanan gelişmeler sonraları sanayi alanında üretim yapan işletmelerin de ilgisini çekmiştir. Savaş süresince devletlerin varlıklarını korumak için geliştirdikleri lojistik sistemi, başka bir deyişle hayatta kalma mücadelesini ticari işletmeler bir rekabet aracı haline dönüştürmüştür. Devletlerin savaş sürecinde kazanmış oldukları lojistik yetenekler, savaştan sonra özel sektörün kullanımına sunulmuştur. 1990'larda işletmeler varlıklarını rekabetçi bir ortamda sürdürebilmek için nakliyeye önem vermişlerdir. Mesafelerin uzunluğu ve zaman yönetiminin önemi rekabetçi faktörler olarak öne çıkmıştır ve işletmeler de çeşitli ulaşım sistemlerini kullanabilen etkin ulaştırma sistemine doğru yönelmişlerdir. Daha açık bir ifade ile ulaştırma sistemlerinin kontrolü önemli bir faktör haline gelmiştir. İşletmeler, faaliyetlerinin hızını korumak ve pazar paylarını kaybetmemek adına, lojistiği stratejik açıdan ele almaya başlamışlardır (www.morethanshipping.com ).

\section{1. İşletme Lojistiğinin Gelişimi: Lojistik Yönetimi ve Tedarik Zinciri Yönetimi Olguları}

1950’li yıllarda lojistik başlı başına bir disiplin iken, gelişen ekonomik ilişkiler içerisinde "Lojistik Yönetimi” ve "Tedarik Zinciri Yönetimi” kavramları ortaya çıkmıştır. Bu bağlamda lojistik, ürünün üretildiği noktadan tüketildiği noktaya kadar ki hareketini sağlayan sistem olarak kavramsallaşmıştır. Günümüzde bu kavram bir mal, hizmet veya bilginin, doğru yer ve doğru zamanda uygun maliyetle bulundurulmasını hedefleyen sistem olarak genişlemiştir.

Lojistik kavramı, "müşteri ihtiyaçlarını karşılamak amacıyla kaynağından tüketim noktasına kadar hammadde, yarı mamul, bitmiş ürün, hizmetin ve ilgili bilgilerin etkin, verimli ve uygun maliyetli olacak şekilde depolama ve akışının planlanması, uygulanması ve denetlenmesi süreci” olarak genişlemiştir (Acar 2010, 5).

Böylece lojistik yönetimi kavramı öne çıkmıştır. Bu noktada lojistik yönetiminin temel amacının, müşterilerin istediği ürünü istediği zaman, yer ve miktarda temin edebilmesi; ulaştırma ve dağıtımdan, hammadde, yarı mamul ve bitmiş ürünlerin stoklanmasına kadar olan maliyetleri minimize edilmesi olduğunu da belirtmekte yarar vardır. Mal, hizmet ve bilginin üretim noktasından son kullanıcı olan tüketiciye kadar ya da bunun tersi yönündeki süreçlerin yönetimi olarak adlandırılan Lojistik Yönetimi kavramı ekonomik ve işletme düzeyindeki gelişmelerin bir sonucudur ve işletme düzeyindeki lojistik faaliyetlerin bilimsel yönden uygulama olanağını genişletmiştir. Örneğin, 1956 yılında Amerika'da deniz taşımacılığında kullanılmak üzere, konteynerin kullanışı, deniz ticareti açısından bir devrim niteliğindedir (Cuturela ve Manole 2013, 195).

Ordu komutanları, eski zamanlardan bu yana lojistiğin kritik rolünü anlamış olsalar da ticari işletmelerin, lojistik yönetiminin rekabet avantajı elde etmedeki yaşamsal rolünü geç fark ettikleri görülmektedir. İşletmelerdeki bu farkındalık eksikliğinin, bütünleşmiş (entegre) lojistiğin faydalarının tam anlamıyla görülememesinden kaynaklanmış olduğu düşünülmektedir. Öyle ki, ticari işletmelerin lojistik yönetiminin temel prensiplerini yaygın olarak kabul görmeleri neredeyse yüz yıl almıştır (Christopher 2011, 2). İşletmelerin lojistiğin önemini anlamalarının ana nedeni, Amerikan sanayisinde 1950'lerde durgunluğunun ortaya çıkması ve bu durgunluğun ancak işletmelerin üretilen malların taşınmasında lojistiğin temel ilkelerini etkin uygulamak suretiyle aşabilmesi olmuştur.

Lojistiğin gelişmesine ve bilimselliğine katkı yapan en önemli öğelerden birisi küreselleşme olgusudur. Küreselleşmenin sosyal, ekonomik, teknik ve politik-yasama güçleri, tedarik zincirini yönetmedeki karmaşıklığın artması dahil olmak üzere, işletme fonksiyonlarının tüm alanlarını etkilemektedir (Szymonik 2014, 1). Küreselleşme, bölgesel ve küresel ticaretin önündeki engellerin kaldırılması süreci ile ilişkindir (Cuturela ve Monole 2013, 189). Yirminci yüzyılın ikinci yarısında güçlenmeye başlayan küreselleşme dönemi (Szymonik 2014, 2) ile merkezi üretim yapısından dağınıkparçalı üretim yapısına geçişi hızlandırmıştır. Ayrıca, bir ürününün maliyet açısından farklı bölge veya devletlerde üretilmesi küreselleşmeye katkı sağlamıştır. Bu tür bir üretim yönetimi ticari döviz hareketliliğini arttırmış, dolayısıyla lojistik stratejilerinde bir değişiklik yapılmasını gerektirmiş ve özellikle ulaşımın stratejisini, yönetimini ve lojistiğini etkilemiștir (Cuturela ve Manole 2013, 189).

Ekonominin küreselleşmesinde, ulaştırma, küresel dışsatım ve dışalım pazarları ile küresel üretimi birbirine bağlamada önemli rol oynamıştır. 1950'lerden sonra bu yöndeki hızlı gelişmeler lojistiğin işletme açısından önemini belirgin hale getirmiştir. Çünkü teknolojik gelişmelerin yanı sıra, yönetim ilkelerinin geliştirilmesi, malların hareketini, teslimatlarının hızını ve hizmet kalitesinin etkinliğini artırmıştır. Ayrıca işletme maliyetlerinin, tesislerin kullanımının, enerji kaynakların daha etkin olmasını sağlamıştır. Bu faktörlerin bir sonucu olarak, lojistikteki doğrudan yatırımlar hızla 
artmış ve lojistik, iletişim ve ulaştırma sektörlerindeki altyapı yatırımlarının (elektrik, gaz, su) oranı önemli ölçüde artmıştır (Cuturela ve Manole 2013, 189).

Lojistiğin askeri alandan işletme lojistiğine dönüşme süreci işletme yönetiminde büyük değişimlere neden olmuştur. 1950’lerde, ilk ve en önemli dönüşüm, imalat işletmelerindeki fiziksel dağıtımın ayrı bir fonksiyon olarak ele alınması olmuştur. Fiziksel dağıtımın ayrı bir fonksiyon olarak ele alınması işletmenin kârlılığına yansımış, bu da lojistiği önemini belirgin bir şeklide arttırmıştır (Heskett vd. 1973).

1960'lara gelindiğinde, zamana bağlı yük taşımacılığında ray yerine kara yolu tercihi ortaya çıkmıştır. Fiziksel Dă̆ıtım etiketi altında ortaya çıkan depolama, malzeme işleme ve yük taşımacılığının müşterek dikkate alınması ihtiyacını doğurmuştur. Lojistik sisteminde taşımanın öne çıkmasıyla 1963 yılında, ABD’de Ulusal Fiziksel Dă̆ıtım Yönetimi Konseyi kurulmuş ve alanında öncü kuruluş olarak yerini almıştır (McGinnis 1992; Robinson 2015). 1962' deki fiziksel dağıtım yönetimi tamamlanmış ürünlerin müşteriye taşınması faaliyetlerine odaklıydı (McGinnis 1992, 22). Bu nedenle özellikle fiziksel dağıtımın, işletme lojistiği çalışma ve uygulamalarının 1960 ile 1970' lerde ortaya çıktığını söylemek mümkündür. 1960'lardan önce neredeyse başta kayıt tutma olmak üzere tüm işlemler elle yapılmaktaydı. 1960 ve 1970’lerde bilgisayarların kullanılması ile lojistik, depolama ve taşımacılık planlamasında optimizasyon sağlayarak büyük atılım sağlanmıştır (Robinson, 2015).

İnternetin günlük yaşamda kullanılması, toplumda iki büyük değişiklik meydana getirmiştir; ilki toplumsal bilginin küreselleşmesiyle ortaya çıkan ve insanlara sağladığı bilgi miktarındaki muazzam artış; ikincisi ise teknolojik gelişmeye olan talepteki patlamadır (Cuturela ve Manole 2013, 189). İnternet, hızlı bilgi akışının yanı sıra, lojistik faaliyetlerin sanal dünyada yaygınlaşmasına, optimizasyonuna, depo işlemlerinin sayısal veriler üzerinden kolayca yapılmasına imkân sağlamıştır. Diğer yandan internetle birlikte yeniliklerin ve teknolojik gelişmelerin takibi kolaylaşmıştır. İnternet küresel çapta bireylerin ve kurumların alışveriş tercihleri çeşitlendirmiş, ticaretin şeklinin değişmesinde etkili olmuştur. Böylelikle internet, e-ticaret kavramını doğurmuştur. Günümüzde "e-ticaretin hızına yetişebilmek için lojistik sektörü ve perakendeci firmalar başat olmak üzere e-ticaretle ilişkili tüm tarafların teknoloji yatırımları yapması zorunlu hale gelmiştir" (UTIKKAD 2019, 4).

20. yüzyıl boyunca lojistik düşüncenin evrimine yönelik önemli safhalar şöyle betimlenebilir (Grant 2012, 5);

1. Dönem: Tarımdan Pazar ekonomine geçiş (1916-1940)

2. Dönem: Parçalı Fonksiyonlar (1940-1960'ın erken dönemi)

3. Dönem: Birleşik Fonksiyonlar (1960'1n erken dönemi-1970’ler)

4. Dönem: Müşteri Odaklı (1970'ler-1980'nin ortalarına kadar)

5. Dönem: Farklılaştırılmış olarak lojistik (1980'nin ortalarından günümüze kadar)

6. Dönem: Davranışsal ve Sınırları (Boundary Spanning) (Gelecek)

Lojistik sistem ilk iki dönemde, pazar sistemiyle bütünleşmiş ancak, İkinci Dünya Savaşı'na kadar her iki dönemde ağırlıklı olarak, tarım ekonomisinden etkilenmiştir. Savaş zamanında askeri lojistik malzeme konusunda faaliyetlere ağırlık verirken, işletme lojistiği ise, pazarlamanın fiziksel dağıtım odaklı bir alt fonksiyonu olarak kalmıştır (Grant 2012, 5).

İş lojistiği, savaştan sonra teknolojik ve ürün yenilikleri ile genişleyen ekonomi ile önemli bir atılım yapmıştır. Yukarıdaki 3-6 dönemleri, son altmış yıldaki lojistikte meydan gelen ilerlemelerin bir sonucu olarak görülebilir.

Tüm bunların yanı sıra, lojistik sektörünün önemi “'Sovyetler Birliği’nin yıkılması, Dünya Ticaret Örgütü’nün (DTO)- World Trade Organization (WTO) etkinliğinin artması, Çin'in 2001 yılında DTO' ya üye olması ve Avrupa Birliği (AB) üyelerinin ortak para birimi olan avroya geçmesi ve birliğin üye sayısının artması ile hız kazanmıştır" (Gümüş 2013, 307).

\subsection{Fiziksel Dă̆ıtımdan, Tedarik Zinciri Yönetimine ve Lojistik 4.0’a}

Tedarik Zincirinin endüstri mühendisliği içine alarak derinleşmesi Fredrick Taylor'ın 1911 yılında, The Principles of Scientific Management (Bilimsel Yönetimin Temelleri) adlı eserini yayımlaması ile başlamıştır. Tedarik zinciri yönetimi son 100 yılda göreceli olarak basit ama emek yoğun süreçlerden, günümüzdeki mühendisliğe ve çok karmaşık küresel ağların yönetilmesine evrilmiştir (Robinson 2015).

1940'lar ve 1950'lerde, lojistik araştırmanın odak noktası, malzeme kullanımındaki çok yoğun emek süreçlerini iyileştirmek için makineleşmenin (örneğin paletler ve palet kaldırıcılar) nasıl kullanılacağı ile raflama ve daha iyi depo tasarımı kullanılarak alandan daha iyi nasıl yararlanacağı üzerineydi. 1950’lerin ortalarında bu kavram, gemileri, trenleri ve kamyonları esas alan intermodal konteynerlerin geliştirilmesi ile ulaştırma/taşıma yönetiminin gelişmesini katkı sağlamıştır (Robinson 2015). 1950'den sonra işletme lojistiğine dönüşen lojistik, önce demiryolu, sonra ise kara yolu ve ardından intermode taşımacılık perspektifinde gelişme gösterdi ve bir ürünün istenilen yer ve zamanda teslimini gerçekleştirme yönünde önemli adımlar atılmış oldu.

Tedarik Zinciri Yönetimi (TZY)- Supply Chain Mangement (SCM), 1980'li yılların başındaki tanıtımından bu yana genel olarak yönetimde en popüler kavramlardan biri haline gelmiş ve evrimi, yoğun küresel rekabet nedeniyle 1990'larda da devam etmiştir (Habib, 2018). Ayrıca, tedarik zinciri yönetimi 1980'lerde deniz lojistiği alanında da gelişme olanağı bulmuştur. 1980'lerin başında kişisel bilgisayarların ortaya çıkması, lojistik faaliyetlerin daha esnek ve hızlı olması ile lojistiğin gelişmiş kapasite ve yeteneklere ulaşmasına olanak sağlamıştır (Robinson 2015). 
1980'lerin sonlarında ve 1990'ların başlarında, lojistik bir faaliyetten tasarım, tedarik, üretim, dağıtım ve satış gibi karmaşık küresel ağları entegre etmek için gerekli bir işlev olan tedarik zincir yönetimine evirilmiştir. Bu, lojistik faaliyetlerin maliyet ve kapsam nedenleriyle üçüncü taraflara daha fazla dış kaynak kullanımına paralel olarak gerçekleşmiştir. Küreselleşmeyle ve dış kaynak kullanımıyla birlikte, nihai bir tüketiciye basit bir ürün getirme konusunda tarafların sayısı önemli ölçüde artmıştır. İşletmeler ayrıca, tedarik sürecindeki tüm tarafların, maliyet, kalite, hız, çeşitlilik ve yenilik açısından nihai tüketiciye ulaşmada önemli katkı sağladığını fark etmeye başlamışlardır. Böylelikle, artık tedarik zincirinin karmaşık yapısını koordine eden tedarik zinciri yönetimi doğmuştur (Wassenhove ve Kleindorfer 2004; Tomasini ve Wassenhove 2009).

1985 yılında, Fiziki Dağıtım Yönetimi Ulusal Konseyi adını Lojistik Yönetimi Konseyi olarak değiştirmiştir. İsim değişikliğinin gerekçesi ise, ortaya çıkan disiplinin gereklerine uygun yapılandırmaya uyum sağlamaktır (Robinson 2015). Çünkü o yıllarda lojistik yönetimi, tedarik zinciri olgusuyla birlikte değerlendirilmeye başlanmıştır. Lojistik olgusu sadece, bir malın taşınmasından ziyade, o malın üretimini, kaynak ihtiyacını, ulaştırma modellerini, stok ve depolama, müşteri hizmetlerini kapsayan daha karmaşı ve tümleşik bir sisteme dönüşmüştür. Böylelikle, sistem tedarik zinciri kavramı ile açıklanmaya başlanmıştır.

Tedarik zinciri, iş süreçlerinin yönetimi veya koordinasyonla ilgili faaliyetler olarak açıklanabilir, çünkü tedarik zinciri ağında bağlantılar vardır. Ağlar, üretilen ve dağıtılan malların, çoklu işletmelerin değişik boyut ve tiplerinden oluşmaktadır. Bu ağların fonksiyonları, hammaddeleri tamamlanmış ürünlere dönüştürmek ve bu ürünleri son kullanıcılara verimli ve etkili taşımaktır (Azmia vd. 2017, 74).

Lojistik hizmetlerdeki gelişmelerin diş ticaret kanallarından etkilenmesi Tedarik Zinciri teriminin yaygın olarak tanınmasına imkân vermiştir. Tedarik Zinciri kavramı 1990'ların ortasından itibaren, özellikle Çin'de üretimin küreselleşmesinin bir sonucu olarak ortaya çıkmıştır. Çin'den yapılan ABD ithalatı, 1995'te yılda yaklaşık 45 milyar dolarlık bir artışla 2006 'da 280 milyar doları aşmıştır (Robinson 2015). Öte yandan, günümüzde dünyanın en büyük iki ekonomisi aynı zamanda birbirlerinin en büyük ticaret ortakları haline gelmişlerdir. 2017 yılına bakıldı̆̆ında, ABD ile Çin arasında gerçekleşen ticaret hacmi 635,5 milyar dolar ile önemli bir tırmanışa geçmiş ve rekor seviyeye ulaşmıştır. Bahsi geçen ticaret hacminin yaklaşı 130 milyar dolarlık pay ABD'nin ihracatına, 505,5 milyar dolarlık pay ise Çin'in ihracatına dayanmaktadır (www.ntv.com.tr).

Bu süreçte, tedarik zinciri yönetiminin stratejik; lojistiğin ise taktik ve operasyonel konulara odaklanması şeklinde bir eğilim ortaya çıkmıştır. İşletme düzeyindeki cari ve kısa dönemsel faaliyetler ağırlıklı olarak lojistik faaliyetler kapsamına girmiştir. Tedarik zinciri ise, işletmenin stratejik konuları ve uzun süreçli faaliyetlerine odaklı bir kavram olarak görülmüştür. Ancak, işletme düzeyinde karmaşıklaşan yönetim, üretim, dağıtım, müşteri ilişkileri gibi hususlar tedarik zincirinin ağırlığını ve kapsamını genişletmiştir. Tedarik zinciri yönetiminin strateji ile bu şekilde bir araya gelmesi, Lojistik Yönetimi Konseyi’ nin adını 2005 yılında Tedarik Zinciri Yönetimi Uzmanlar Konseyi' ne dönüştürmesine neden olmuştur (Robinson 2015). Yine yapılan bazı çalışmalarda, tedarik yönetiminin bir işletmenin üretim veya hizmet odaklı- temel işlevlerinden biri olduğunu ifade etmektedir. Tedarik yönetimi kavramı, yıllarca diğer ilgili alanları kapsayacak şekilde satın alma konusuna odaklanmıştır. Tedarik yönetimi, işletmelerin stratejik planlama işlevleri için önemli olmuştur. TZY' nin tarihi gelişimine bakıldığında, Charles Babbage' in 1832'de yayınladığı makine ve üretim ekonomisi hakkındaki kitabında satın alma işlevinin önemine değindiği görülmektedir. Satın alma sürecinin en büyük gelişimi, 1850'li yıllardan sonra Amerikan demiryolunun büyümesi ile sağlanmıştır. Bu, satın alma fonksiyonun, genel şirket kârlılığına katkıda bulunan, ayrı bir kurumsal işlev olarak tanınmasına yol açmıştır. 1900-1939 yılları arası dönemde geliştirilen tedarik zincirinin modern satın alma işlevlerinin temel unsurları ise Birinci Dünya Savaşı'nda (19141918), özellikle hammadde teminine odaklanarak, savaş malzemelerinin satın alınması için uygulanmıştır. İkinci Dünya Savaşı sırasında (1939-45), satın alma girişlerinin kurumsal önemi gittikçe daha fazla fark edilmiş ve çeşitli ABD üniversitelerinde işletme lojistiği dersleri verilmiştir. Ayrıca savaş sonrası dönem, pazar yönelimli işletmelerin sayısında önemli artışlar oluşturmuştur (Keane, Herbohn ve Slaughter 2003, 24).

1970'lerin sonunda ve 1980'lerin başlarında, dünyada ticari yaşam büyük ölçüde değişmiş ve küreselleşme, otomasyon, teknolojik değişim, artan enflasyon, uluslararası rekabet ve stratejik ittifaklardan etkilenilmiştir. Bu değişiklikler TZY' yi etkilemiş ve müşterilerin talepleri ve gereksinimleri ile tedarikçilerin rollerinin önem kazandığ1 bütünleşmiş bir yaklaşıma evrilmiştir. Satın alma ve malzeme yönetimi, genel organizasyona değer katmak ve kârlılığını arttırmak için önemli bir unsur olarak görülmektedir. Ayrıca dünya çapındaki rekabetin, hızla değişen teknoloji ve müşteri beklentilerinin karşılanmasında büyük bir etkisi olduğu bilinmektedir (Keane vd. 2003, 24).

1990'larda “Kurumsal Kaynak Planlaması” (ERP) sistemlerinin ortaya çıkmasıyla lojistik daha da büyümüştür. ERP yazılımı, lojistik bileşenler arasında daha iyi planlama ve entegrasyon ihtiyacının fark edilmesini önemli ölçüde artırmıştır (Robinson 2015).

Buraya kadar anlatıldığı üzere, tedarik zinciri sürecinin bir parçası olarak lojistiğin; malların, hizmetlerin ve bilgilerin verimli, etkili bir biçimde üretim noktasından tüketim noktasına, akışını planlayan, uygulayan ve kontrol eden sistem olarak ifade edildiği söylenebilir. TZY ise, bireysel işletmelerin uzun vadeli performansını ve bir bütün olarak tedarik zincirini iyileştirilmesi amacıyla geleneksel işletme fonksiyonlarının sistematik ve stratejik koordinasyonudur (Robinson 2015). Bu bağlamda, Larson ve Halldórsson (2004, 18-21) lojistik ve tedarik zinciri kavramları arasında aşağıdaki gibi dört tür etkileşimin olduğunu ifade etmişlerdir; 
Gelenekselciler: Geleneksel görüşe göre, tedarik zinciri lojistiğin bir parçasıdır. Bu yaklaşım, işletme açısından, lojistiğin esas unsur olduğunu, TZY' nin ise ikincil derecede ve lojistiğin bir alt unsur olduğunu ileri sürmektedir.

Yeniden etiketleme: $\mathrm{Bu}$ görüş, tedarik zinciri ile lojistik arasında bir fark olmadığını aynı anlamı içerdiğini, tedarik zincirinin sadece lojistiğin isim değişikliği hali olarak görmektedir. Ancak bu görüş, çok kabul edilen bir yaklaşım değildir.

Birlikçiler: Pek çok araştırmacı TZY' nin kurumlar arası bir süreç / iş birliği olduğunu, lojistiğin ise, şirket işlevinin içinde olduğunu düşünmektedir. Bu görüşe göre, lojistik, tedarik zincirinin bir alt öğesidir, TZY lojistiği kapsamaktadır. Bu görüş ABD merkezli bir görüşü yansıtmaktadır ve en yaygın olan görüştür.

Kesişimci: Birçok uygulayıcı, her iki terimin de bazı örtüşen kapsamları olan iki farklı kavramı olduğunu belirtmiştir. Her iki kavramın bazı benzerlikleri içerdiği ancak, farklılıkları olduğunu da ima etmektedir.

Şekil 1'de TKY ve Lojistik üzerine bakış açıları yer almaktadır.

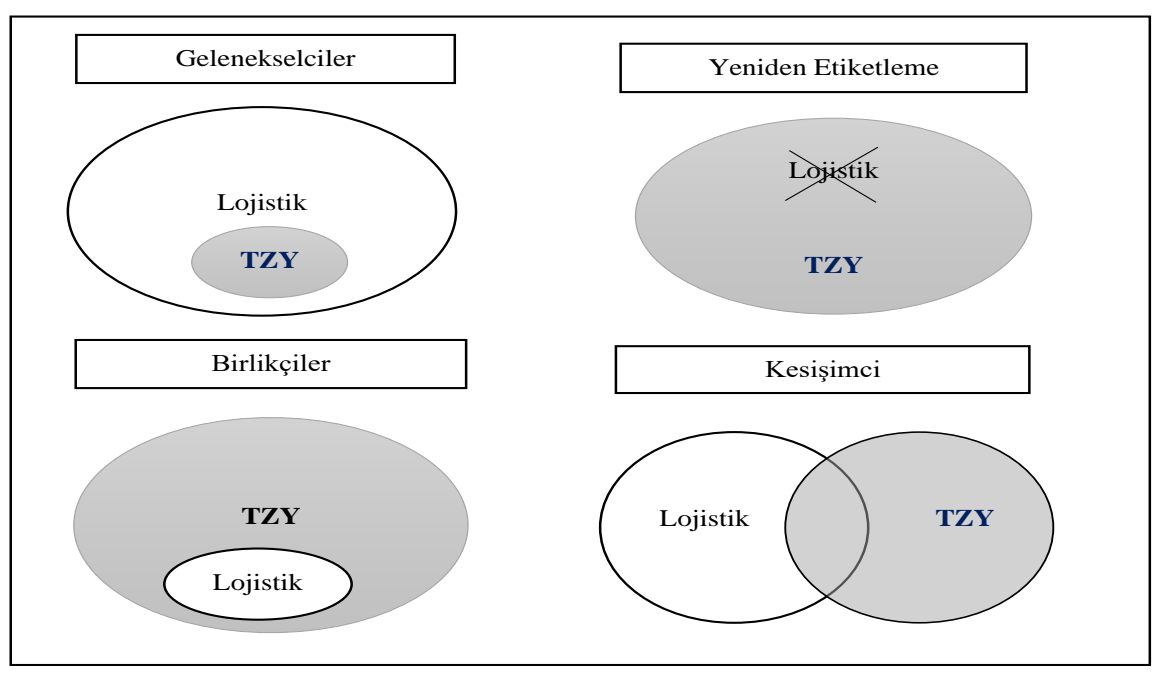

Şekil 1. TZY ve Lojistik Üzerine Bakış açıları

Kaynak: Larson, Poist ve Halldórsson 2007, 3

Sonuç olarak, günümüzde birçok işletme tedarik ağlarını entegre etmeye çalışmaktadır. Bunun dünya çapında tedarikçi ve distribütör katmanı içeren ve farklı taşıma modları ve taşıyıcıları ile farklı üretim metotları vasıtası ile yapmaktadır. Entegrasyon süreci şirketlerin taşıma, depolama ve yönetme şeklini değiştirmiştir. Bu bütünleşmeler, lojistik sistemleri büyük ölçüde geliştirmiş ve işletmelere yeni bir stratejik önem kazandırmıştır (Mckinnon 2001, 157).

Sektörün tüm üretim ve hizmet unsurlarıyla yakın bir ilişki içinde olması Endüstri 4.0 değişimine de uyum sağlamasını gerektirmiştir. Lojistik faaliyetleri yürüten işletmelerin, sürdürülebilir rekabet avantajı sağlaması açısından günümüzde ve gelecekte sayısal ortamlarda akıllı çözümler oluşturmayı ve otomasyona dayandırmayı önemle ele almaları gerekmektedir. Geçmişte bu alandaki işletmeler için rekabette kritik faktörler verimlilik, standardizasyon ve düşük maliyetken, bugün ve gelecekte proaktif olmak, çeviklik, müşteri odaklı hareket etmek, esnek ve yenilikçi olmak başarıya giden yolda kritik faktörler haline gelmiştir. Bu anlamda Lojistik 4.0 kavramının da öne çıktığını görmekteyiz Lojistik 4.0, "üreticiden üçüncü parti lojistik firmaları aracılığıyla müşterilere kadar tedarik zincirindeki tüm firmaların, yüksek bağlantılı süreçlerinin, verilerinin ve sistemlerinin bütünleştirilmesi ve entegrasyonu" (Yılmaz ve Duman 2019, 190) olarak ifade edilebilir. Lojistik sektörünün, neredeyse diğer tüm üretim ve hizmet sektörü ile yakın ilişki içerisinde olması, endüstride olası değişimlere uyum sağlaması gerekliliğini beraberinde getirmektedir. Lojistik süreçlerin tamamen fiziksel olarak ele alınması, lojistik hizmet sağlayıcılarının rekabetçi olabilmeleri için yeterli değildir (Yılmaz ve Duman 2019).

Ayrıca, lojistik günümüzde çok faklı alanları kapsayacak biçimde genişlemiştir. Bu noktada, mal ve hizmetlerin müşteriden perakendeci, toptancı veya üreticiye geri doğru taşınmasını inceleyen Tersine Lojistik kavramı; sosyal sorumluluğu ve çevreyi dikkate alan Yeşil Lojistik (Kazancoglu vd. 2018a; Kazancoglu vd. 2018b) kavramı; malları ulaştırma ve taşınma biçimlerine göre inceleyen kara yolu, deniz yolu, hava yolu, demir yolu lojistiği konseptleri veya taşınan malların cinsine göre betimleme yapan Gida Lojistiği veya Enerji Lojistiği, doğal ve yapay afetlerde felaketzedelere yardımı öngören Doğal Afet Lojistiği (Koçak vd. 2019) gibi yeni kavram ve konseptler geliştirilmiştir.

\section{Lojistik Stratejisinin Tarihsel Evrim Dinamiği}

Strateji sözcük olarak farklı anlamları içeren bir kavramdır. Etimolojik açıdan Klasik Yunan'a uzandığı ifade edilen strateji kavramı, temelde liderin gösterdiği yolu işaret etmektedir (Aşcı 2017, 15). Türk Dil Kurumu'nun (2019) tanımına göre strateji, "Bir ulusun veya uluslar topluluğunun, barış ve savaşta benimsenen politikalara destek vermek amacıyla politik, ekonomik, psikolojik ve askerî güçleri bir arada kullanma bilimi ve sanatıdır”. Bu tanım askeri bir anlam içermektedir. Çıkış noktası da askeri kökenli olması nedeniyle bir bakıma savaş sanatı olarak ifade edilebilir. 
Lojistik stratejileri tarihsel süreçte var olmuştur, ancak bilimsel anlamda analizleri ve betimlenmesi kapitalizmin küresel ölçekte yaygın olmasıyla ortaya çıkmıştır. Bu bağlamda, ticari faaliyette bulunan bireyler veya işletmeler ticari faaliyetin kısa, orta, uzun vadedeki hedef ve amaçlarını belirlemek, buna uygun olarak iş stratejilerini betimlemek gibi faaliyette bulunmuşlardır. Örneğin, Büyük İskender'in fetihleri veya Asya'daki karavan ticaret yolları binlerce yıl önceden lojistik stratejisinin adımları olarak görülebilir. Akademik disiplin tarafindan bilimsel analizler ise 1960’l1 yıllarda yapılmaya başlanmıştır. Lojistik ve pazarlama arasındaki ilişki bağlamında lojistik veya fiziksel lojistiği, stratejik bir odak noktası halinde ilk kez inceleyip 1969 yılında Journal of Marketing dergisinde kaleme alan kişi Donald Bowersox'dır (Grant 2012, 254-255).

Ticari faaliyete indirgendiğinde lojistik; "müşteri taleplerini ve ihtiyaçlarını karşılamak amacıyla ham maddenin tedarik aşamasından başlayan ve ürünün tüketilmesine kadar geçen süreci kapsayan, ürünlerin depolanmasını, planlanmas1, uygulanması ve kontrol edilmesi sürecidir" (Yangınlar ve Bal 2019, 154). Lojistik stratejinin temeli ise; işletme stratejisine dayanmaktadır. Bir ticari işletmenin rekabet gücü sayesinde karlılığını ve verimliliğini artırmaya yönelik alabileceği uzun vadeli tedbirler işletme stratejisi kapsamında değerlendirilir. Bu kapsamda, Grant (2012, 241) tarafindan işletme stratejisi "bir kuruluşun, değişen bir ortamda kaynakları yapılandırması, pazarların ihtiyaçlarını karşılama ve paydaş beklentilerini yerine getirme yoluyla kuruluş için avantaj sağlayan uzun vadede kuruluşun yönü ve kapsamı" olarak ifade edilmektedir.

Lojistikte strateji, icradan ziyade planlama yapmakla ilgilidir. Strateji, günlük sorunları çözmekten farklı olarak, tedarik zinciri için uzun vadeli bir planın oluşturulmasına dayanır (Harrison ve Hoek, 2008: 26). Bu nedenle, lojistik stratejiyi kavramsal olarak, "dinamik ve zorlu bir rekabet ortamında istenen hedeflere ulaşmak için önemli kaynakları geliştirme ve kullanma çabalarında işletmeye rehberlik etmek” olarak betimlemek mümkündür (Mckinnon 2001, 162). Yine, Lojistik Yönetimi Konseyi, lojistik stratejiyi "işletmenin uzun vadeli hedeflerini belirleme ve bu hedefleri gerçekleştirmek için önemli paydaşların endişelerini ve gelecekteki beklentilerini dikkate alan uzun vadede alınması gereken esaslar" olarak tarif etmiştir. Özetle, lojistik stratejisi, bir işletmenin lojistik faaliyetlerini en etkin şekilde yürütmek amacıyla, ortaya koyulması gereken uzun vadeli prensipler ve esaslardır (Mckinnon 2001, 162).

Lojistik stratejinin bilimsel tartışmaya konu olmasıyla birlikte zamanla kapsamı da genişlemiştir. Örneğin, çeşitli ürün hizmetleri, özellikle depolama maliyetleri lojistik strateji kavramına dahil edilmiştir. Bu gelişmelerden sonra 1980'lerde Bowersox ve Patricia Daugherty (1987) tarafından lojistik stratejisinde üç önemli unsur ortaya koyan bir tipoloji sunulmuştur. Bunlar; süreç, pazar ve bilgi kanalı stratejisidir (McGinnis, Kara ve Wolfe 2016, 36).

Süreç stratejisi, maliyetleri kontrol etmenin temel amacı olan geleneksel lojistik faaliyetlerin yönetimi ile ilgilidir, başka bir deyişle bir verimlilik stratejisidir. Pazar stratejisi ise, müşterilerin karşılaştıkları karmaşıklığı azaltmak amacıyla, seçilen geleneksel lojistik faaliyetlerinin iş birimleri arasında yönetimi ile ilgili bir piyasa stratejisidir, yani bir etkinlik stratejisidir. Bilgi stratejisi, organizasyonlar arası koordinasyon ve iş birliğini sağlamak amacıyla bir sistem olarak yönetilen çeşitli geleneksel ve diğer faaliyetlerin bir araya getirilmesiyle ilgilidir, diğer bir bakış açısıyla daha geniş bir tedarik zinciri konuları ile ilgilenilmesi stratejisidir (Grant 2012, 255). Bilgi Stratejisi, Bowersox ve Daugherty (1987) tarafından genellikle lojistikte yer almayan faaliyetler (veri işleme, emlak, bayi hizmetleri ve tesisler) olarak özetlenir. $\mathrm{Bu}$ stratejinin vurgusu diş kontrole öncelik verilmesi üzerinedir ve organizasyonlar arası koordinasyonun gereksinimlerine karşı oldukça hassastır (McGinnis vd. 2016, 38).

Sonraki araştırmacılar bu sınıflandırma temeli araştırmalardan elde edilen bulguları sentezleyen ve test eden çalışmalar yapmışlardır. Buna göre, maliyet ve müşteri gereksiniminin en hızlı şekilde karşılama konusunda güçlü bir rekabetin yaşandığı bir durumda, bir işletmenin muhtemelen yoğun bir lojistik stratejiye ihtiyacı olacağını; bununla birlikte, bir işletmenin rekabet avantajı kaynağı teknolojik baskınlığa, ürün özelliklerine, istisnai marka kabulüne veya istisnai maliyet avantajlarına dayanıyorsa, pasif bir lojistik stratejisine ihtiyaç duyacağı şeklinde bilimsel araştırmalar yapılmıştır. Son yıllarda, "yoğun” lojistik stratejilerinin yüzdesinin artmış olması, lojistik sürecinin genel örgütsel stratejideki öneminin arttığını göstermektedir (Grant 2012, 255-256).

\section{Sonuç}

Lojistik, başlangıçta orduların ikmalini desteklemek için kullanılan bir kavram ve faaliyet olarak ortaya çıkmış ve 20 . yüzyılın başlarına kadar olgunun varlığı devam etmiştir. Ancak, tarihsel süreç içinde, askeri nitelikli lojistik, daha sonra, ekonomik ve ticaretin gelişmesi, teknolojik buluşlar ve işletme düzeyinde etkinliklerin gelişimine bağlı olarak, işletme lojistiğine dönüşmüş ve bu durum 1950'li yıllardan sonra gelişme göstermiştir.

İşletme lojistiğinin teknolojik ve ekonomik gelişmeye paralel olarak, odak noktası başlangıçta, malların fiziki dağıtımını öngördüğünden, kavram olarak "fiziksel dağıtım” şeklinde nitelendirilmiştir. Ancak işletme lojistiği, daha sonra, lojistik yönetimi ve tedarik zinciri yönetimi şeklinde fonksiyonel ayırıma gitmiştir. Kuramsal çalışmalar bağlanımında, her iki kavramın ilişkisi açısından farklı görüşler ileri sürülmüştür.

Tarihsel süreç içinde askeri bir nitelikten ekonomik niteliğe dönüşen lojistik kavramı küreselleşme olgusuyla birlikte sürekli gelişim içinde olmuştur. 1990’lı yıllara gelindiğinde devletler serbest piyasa ekonomisini destekleyen politik kararlar alarak; dış ticarete engel olan kısıtlamalar kaldırılmış, gümrük tarifelerinde uygulanan indirimlerle dış ticaret kanalının önü açılmıştır (Gümüş 2013, 307). Lojistik sektörü de liberalleşen ve küreselleşen piyasada ulaşım ve iletişim teknolojisindeki gelişmelerin yardımıyla küresel ticarette ve ülke ekonomilerinde önemli yer tutmaya başlamıştır. 
Endüstri 4.0’’n etkisi lojistik sektöründe de kendini göstermiştir. Bu bağlamda, lojistik faaliyetlerde dijitalleşmeye uyum baş göstermiş ve Lojistik 4.0 kavramı ön plana çıkmıştır.

Gelinen noktada, yapılan inceleme ve araştırmalar, "gelişmiş ülkelerde GSMH'nin \%12-15'ini lojistik sektörünün oluşturduğunu ortaya koymaktadır” (Elgün 2011, 49). Şüphesizdir ki küreselleşmenin ve uluslararası ticaret hacminin giderek arttığı dünyamızda, lojistiğin önemi ve ticaretteki payı ivmeli bir şekilde artmaya devam edecektir. 


\section{KAYNAKÇA}

Acar, Z. A. 2010. "Lojistik Yeteneklerin, Strateji- Performans İlişkisi Üzerindeki Rolü: Kobi'ler Üzerinde Bir Saha Araştırması". Atatürk Üniversitesi İktisadi ve İdari Bilimler Dergisi, 24 (4),1-21.

Aşc1, B. H. 2017. Ordulardan Şirketlere Strateji. Siyasal Yayınevi: Ankara.

Azmia, I., Hamid, N. A., Hussin, M. N. M. ve Ibtishamiah, N. 2017.” Logistics And Supply Chain Management: The Importance of Integration For Business Processes." Journal of Emerging Economies and Islamic Research, $5(4), 73-80$.

Ballou, R. H. 2007. "The Evolution And Future of Logistics And Supply Chain Management." European Business Review, 19 (4), 332- 348.

Christopher, M. 2011. Logistics and Supply Chain Management. Fourth Edition, Pearson:UK.

Cuturela, S. C. ve Manole, A. 2013. "A Short Historical Perspective on The Evolution of Logistics And İts Implications For Globalization, Revista Română De Statistică Trim, 188-198. http://www.revistadestatistica.ro/suplimente/2013/3_2013/srrs3_2013a23.pdf, Erişim 29 Temmuz 2019.

Çetin, M. ve Kök, R. 2015. “Askerî Devrim Bağlamında Batı Savaş Lojistiğinin Tarihsel Gelişimi.” Siyaset, Ekonomi ve Yönetim Araştırmaları Dergisi, 3 (4).

Elgün, N. M. 2011. "Uluslararası Taşıma ve Ticarette Lojistik Köylerin Sağladığı Rekabet Avantajları: Bir Model Önerisi.” Afyon Kocatepe Sosyal Bilimler Enstitüsü, Yayımlanmamış Doktora Tezi.

Erdönmez, S. E.ve İncaz, S. 2016. "2018 Yılına Kadar AB Denizyolu Taşımacilığının Stratejik Hedefleri ve Önerilerinin Türkiye'ye Yansıması." Journal of Emerging Economies and Policy, 1, 112-125.

Erkan, B. 2014. "Türkiye'de Lojistik Sektörü ve Rekabet Gücü.” ASSAM, 1,45-65.

Fiorin, F. 2019. "Owning the Past, Controlling the Present: The Mosque-Cathedral of Cordoba", https://www.researchgate.net/publication/331408302

Owning_the_Past_Controlling_the_Present_The_Mosque-Cathedral_of_Cordoba, Erişim 2 Ağustos 2019.

Grant, D. B. 2012. Logistics Management, Pearson: UK.

Gümüş, S. 2013. "Lojistik Sektörünün Türk Ekonomisine Katkıları ve Bir Araştırma." Uluslararası İşletme ve Yönetim Dergisi, 1(3), 302-324.

Habib, M. 2018. "Supply Chain Management (SCM): Theory and Evolution.” www.intechopen.com, Erişim: 19 Temmuz 2018.

Hammond M. F. 2012. "Army Logistics and Its Historical Influence", https://alu.army.mil/alog/issues/JanFeb12/Logistics_Historical_Influences.html Erişim 1 Ağustos 2019.

Harrison, A. ve Remko Van H. 2008. Logistics Management and Strategy, Competing through the supply chain. Third Ed., Pearson: UK.

Heskett, J.L., Glaskowsky, N.A. Jr ve Ivie, R.M. 1973. Business Logistics. 2nd ed., The Ronald Press: New York.

http://bestlogisticsguide.com/Basics/Logistics-History/Logistics History Shows The Benefit And Importance of Logistics, Erişim 14 Temmuz 2018.

https://quatr.us/greeks/cargo-ships-ancient-greece.htm Erişim 31 Temmuz 2019.

https://www.britannica.com/topic/logistics-military/Historical-development Erişim 23 Mayıs 2019.

https://www.ntv.com.tr/dunya/abd-cine-ek-vergiden-18-4-milyar-dolar-kazaniyor Erişim 20 Mart 2019.

https://www.supplychainmovement.com/buyuk-iskenderin-lojistik-yetenegi-alexander-the-greats-talent-for-logistics/ Erişim 31 Temmuz 2019.

https://www.supplychainopz.com/2013/05/logistics.html, Erişim 20 Mart 2019.

İşbilir, Ö. 1997. "XVII. Yüzyıl Başlarında Şark Seferlerinin İaşe, İkmal ve Lojistik Meseleleri.” İstanbul Üniversitesi, Yeniçağ Tarihi Bilim Dalı (Basılmamış Doktora Tezi) İstanbul.

Kayıran, M. 1989. “Tekâlif-i Milliye Emirleri ve Uygulanışı.” Atatürk Araştırma Merkezi Dergisi, 5(15), 639-664.

Kazancoglu Y., Kazancoglu I. ve Sagnak M. 2018a. "Fuzzy Dematel-Based Green Supply Chain Management Performance: Application in Cement Industry." Industrial Management \& Data Systems, 118 (2),412-431

Kazancoglu Y., Kazancoglu I., ve Sagnak, M. 2018b. "A New Holistic Conceptual Framework For Green Supply Chainmanagement Performance Assessment Based On Circular Economy." Journal of Cleaner Production, 195,1282-1299.

Keane, R. H., Herbohn, J. ve Slaughter, G. 2003. "Theoretical Background of Supply Chain Management And Potential Supply Chain of North Queensland Timber Industry." In Forestry Symposium, St Lucia, Australia, 23-37.

Koçak, R. D., Demir S. ve Ateş, H. 2019. "Humanitarın Aid Logistics: Scope And Management.” Sefer Yılmaz (edt.), Business and Management, Ankara, Akademisyen Yayinevi, 41-58.

Kurtaran, U. 2012. "Osmanlı Seferlerinde Organizasyon ve Lojistik." International Periodical For The Languages, Literature and History of Turkish or Turkic, 7 (4),2269-2286.

Larson, P.D. ve Halldorsson, A. 2004. "Logistics Versus Supply Chain Management: An International Survey." International Journal of Logistics: Research and Applications, 7(1),17-31, doi: $10.1080 / 13675560310001619240$. 
Larson, P. D., Richard F. P., ve Árni H. 2007. "Perspectives on Logistics vs. SCM: A Survey of SCM Professionals." Journal of Business Logistics 28(1),1-24.

McGinnis, M. A. 1992. "Military Logistics: Insights for Business Logistics." International Journal of Physical Distribution \& Logistics Management, 22(2),22-32. https://doi.org/10.1108/09600039210015356

McGinnis, M. A., Kara, A. ve Wolfe, L. I. 2016. "An Empirically Derived Framework of Logistics Management Strategy." Journal of Transportation Management, 27(1),31-44. doi: 10.22237/jotm/1467331440

Mckinnon, A. 2001. Integrated Logistics Strategies, Handbook of Logistics and Supply Chain Management. Edited by A.M. Brewer et al., Elsevier Science Ltd, 157-170.

Pelletier, J. A. 2013. "From Ancient to Modern Logistics: Evidence in Ancient Egypt \& the Early Development of Marketing." College of Business, University of South Florida, Proceeding, 195-209.

Robinson, A. 2015. "The Evolution and History of Supply Chain Management.” https://cerasis.com/2015/01/23/historyof-supply-chain-management/, Erişim 17 Temmuz 2018.

Sweeney, S. Edward, Grant, D.B. ve John M. 2017. "Strategic Adoption of Logistics and Supply Chain Management." International Journal of Operations and Production Management, 1 November. doi: 10.1108/IJOPM-05-20160258.0258, Erişim 20 Mart 2019.

Szymonik, A. 2014. "Globalization and logistics", https://www.researchgate.net/publication/296706132_Globalization_and_international_logisticsErişim 1 A ğustos 2019

TDK 2019. http://sozluk.gov.tr/ Erişim 31 Temmuz 2019.

Tepic J., Tanackov L. ve Stojić G. 2011. “Ancient Logistics - Historical Timeline And Etymology.” Technical Gazette, 18(3), 379-384, ISSN 1330-3651

Tomasini, R.ve Luk Van W. 2009. Humanitarian Logistics, Uk, Palgrave Macmillan.

UTIKKAD 2019." Türkiye'de E-Ticaret ve E-İhracat Gelişim Potansiyeli ve Lojistik Süreçler",https://www.utikad.org.tr/Images/DosyaYoneticisi/19022019utikadeticaretveeihracatraporu.pdf, Erişim 31 Temmuz 2019.

Wassenhove, LN V. 2006. "Blackett Memorial Lecturew Humanitarian Aid Logistics: Supply Chain Management In High Gear", Journal of The Operational Research Society, 57, 475-489.

Wassenhove, V. L. ve Kleindorfer, P. 2004. "Managing Risks In Global Supply Chains.” The INSEAD-Wharton Alliance On Globalizing: Strategies For Building Successful Global Business. Wharton INSEAD Alliance.

Wolff, R. A. ve Yıldız, D. 2018. “Türkiye'de Lojistik Yönetimindeki Gelişmeler: Stratejik Bir Bakış Açısı”, Social Sciences Research Journal, 7(3),187-198, ISSN: 2147-5237

Yangınlar, G. ve Bal, N. 2019. "Yalın Yönetim ve Yalın Lojistik Kavramlarının İrdelenmesi." Stratejik ve Sosyal Araştırmalar Dergisi, 3 (1),151-161.

Yılmaz, Ü. ve Duman, B. 2019. "Lojistik 4.0 Kavramına Genel Bir Bakış: Geçmişten Bugüne Gelişim ve Değişimi." Bilecik Şeyh Edebali Üniversitesi Sosyal Bilimler Enstitüsü Dergisi, 4(1),186-200, doi: 10.33905/bseusbed.465962. 